\title{
Dispersion of Czechia's Development Assistance Allocated to Priority Partner Countries with the Use of Bilateral Projects ${ }^{1}$
}

Eva KOVÁŘOVÁ*

\begin{abstract}
Czechia has been an ODA donor since the mid-1990s and its ODA was too fragmented in the past. However, no research study has been published so far to address the issue of ODA dispersion in the portfolio of Czech bilateral development projects. The paper aimed to assess dispersion of Czech ODA allocated to priority partner countries with the use of bilateral projects between 2011 and 2019, and to show whether any progress towards lower ODA dispersion has been made since 2011. To meet the aim, concentration measures standardly applied for the analysis of ODA dispersion were used. The findings showed that ODA was dispersed especially in recipient countries that received higher ODA volumes, and that the progress towards more concentrated ODA has been made since 2017.
\end{abstract}

Keywords: Czechia, bilateral projects, dispersion, Official Development Assistance (ODA), priority partner countries

JEL Classification: F35, F60, H81

DOI: https://doi.org/10.31577/ekoncas.2021.10.02

\section{Introduction}

The official development assistance (ODA) is considered one of the most important external resources of finance that can promote socio-economic development in less developed countries, listed as ODA recipients. Relationship between ODA allocations and economic growth or socio-economic development is a frequent research topic. However, it is hard to find any consensus on the intensity

\footnotetext{
* Eva KOVÁŘOVÁ, VŠB-Technical University of Ostrava, Faculty of Economics, Department of Public Economics, Sokolská tř́́da 33, 70200 Ostrava; Czech Republic; e-mail: eva.kovarova@ vsb.cz

${ }^{1}$ This paper was created within the framework of the project SGS SP2021/51 Complex Use of Quantitative Methods in Economic Disciplines, realized the Faculty of Economics, VSB-Technical University of Ostrava, Czech Republic.
} 
of this relationship (Sachs, 2012; 2005; Mallik, 2008; Easterly, 2007; Dalgaard et al., 2004; Collier and Dollar, 2002). On the other hand, a general consensus exists on the relationship between ODA effectiveness related to the ODA outcomes and preconditions for this effectiveness recognized in recipient as well as donor countries. Dispersion of ODA is one of the issues commonly addressed in relation to the ODA effectiveness, and this issue is examined in various circumstances and in the context of different recipient and donor countries.

Czechia, as a member of the Development Assistance Committee of the Organisation of Economic Co-operation and Development (OECD-DAC) belongs to ODA donor countries. Its foreign development cooperation was launched in the mid-1990s and it complies with the international commitments concerning the volume of ODA and its main objectives. Priorities of Czech development cooperation are defined in the Act on Development Cooperation and Humanitarian Aid and by regularly launched strategies. Between years 2011 and 2019, Czechia disbursed 128572050 USD on bilateral development projects in priority partner countries, and realized there more than 800 disbursements related to these projects (Czech Development Agency, 2011 - 2019). Despite the OECD-DAC membership, Czechia spent on ODA (bilateral as well as multilateral) on average $0.12 \%$ of its GNI between years 2011 and 2019 (OECD, 2021), and stayed far behind the international and EU commitments concerning the volume of ODA (defined at the level of $0.70 \%$, resp. $0.33 \%$ ).

In 2016, the OECD-DAC recommended Czechia to reduce the number of priority partner countries and themes of development cooperation in order to decrease the ODA dispersion, as dispersion of Czech ODA and its consequences were highlighted by the OECD-DAC several times (OECD, 2016). The Czech Development Cooperation Strategy adopted for the years 2018 - 2030 introduced reduced number of priority countries and themes (Ministry of Foreign Affairs, 2017). However, the reduced number of priorities cannot be simply considered a progress towards less dispersed ODA. Therefore, research, which findings are presented here, wanted to address the issue of ODA dispersion in such details that enable to identify any progress towards less dispersed ODA and to formulate political recommendations. The aim of this research was to assess dispersion of Czech ODA disbursements allocated to priority countries with the use of bilateral development projects between years 2011 and 2019, and to show whether any progress towards lower ODA dispersion has been made since the year 2011. To meet the aim, methods standardly applied for the assessment of ODA dispersion were used to process the data. ODA disbursements were described first with the tools of descriptive statistics. Dispersion of ODA disbursements between priority partner countries and within these countries was assessed with the use of 
Theil Index that is a standard measure of concentration. However, its standard formulation was updated according to Fløgstad and Hagen (2017). Dispersion of ODA between bilateral projects realized in priority partner countries was assessed with the use of Herfindahl Index. The relationship between dispersion of ODA and its volumes was measured with the use of Pearson Correlation Coefficient.

Presentation of the research is structured as follows: 1. the most important consequences concerning the development cooperation of Czechia and dispersion of ODA are introduced; 2. methodology applied for the assessment of ODA dispersion is explained; 3. main results and findings are interpreted, summarized and discussed; 4. political recommendations are formulated.

\section{Theoretical Background for Analysis}

Patterns of Czech foreign development cooperation have been reviewed and discussed in several research studies published in past ten years. Particular research attention was given to the volumes of ODA flows (Krylová et al., 2012; Majerová, 2013; Horký, 2011) or to their territorial allocation in the context of other external economic relations (Harmáček et al., 2017). Topic of ODA fragmentation was addressed partly by Syrovátka and Krylová (2012) who associated their recommendations with the decrease of ODA dispersion. They calculated the aid component of the Commitment to Development Index and concluded that Czechia would have need to increase aid quantity as well as quality, including lower ODA dispersion, to improve the score. However, dispersion of ODA disbursements allocated with the use of bilateral development projects has not been assessed yet, although ODA dispersion is a topic addressed in the context of other ODA donor countries.

Most recent studies dealing with ODA dispersion revealed that ODA dispersion at least persisted or even worsen when ODA of some OECD-DAC donors was assessed, see the findings of Steinwand and Reinsberg (2020) for the period of years 1990 - 2013; Bickenbach et al. (2019) for the period of years 1995 2015; Fløgstad and Hagen (2017) for the period of years 1998 - 2013; Carrcelli (2018) for the period of years 1990 - 2010; Kilby (2011) for the period of years 1973 - 2008. Fløgstad and Hagen (2017) indicated that ODA dispersion grew globally as the number of donors and recipients grew, and ODA was delivered by many actors with quite similar shares. Bickenbach et al. (2019) highlighted that ODA concentration declined for most OECD-DAC donors they assessed. Steinwand and Reinsberg (2020) argued with continuing dispersion of bilateral ODA, particularly due to growing number of bilateral development projects and their decreasing average sizes. 


\subsection{Priorities of Czech Development Cooperation}

Czechia introduced its official foreign development policy in the mid-1990s. The first strategic concept of development cooperation was launched for the period of years $2002-2007$. Poverty reduction in less developed regions through the economic and social development was stated as the framing objective of development cooperation (Ministry of Foreign Affairs, 2001). The Act on Development Cooperation and Humanitarian Aid, adopted in the year 2010, defined foreign development cooperation as the set of activities financed from the national budget contributing to the eradication of poverty in the context of sustainable development, to economic and social development, to environmental protection, and to the promotion of democracy, human rights and good governance in developing countries (Czechia, 2010). The Act specified powers and responsibilities in the foreign development policy and its financing as well. The Ministry of Foreign Affairs (MoFA) became the main authority responsible for the formulation of strategic priorities. The Act constituted the Czech Development Agency (CZDA) that became an administrative state unit responsible for the identification, formulation and monitoring of bilateral projects realized in partner countries (CZDA, 2021).

The second Development Cooperation Strategy was adopted for the period of years $2010-2017$, following the recommendations introduced by the OECDDAC peer review in 2007. The Strategy introduced the intention to channel development assistance into two groups of countries: 1. programme countries Afghanistan, Bosnia and Hercegovina, Ethiopia, Moldova and Mongolia; 2. project countries - Georgia, Cambodia, Kosovo, Palestinian Autonomous Territories and Serbia (MoFA, 2010, 2021a). ODA was allocated according to five thematic priorities - environment, agriculture, social development, economic development, promotion of democracy, human rights and social transformation (MoFA, 2010). The Strategy confirmed that fragmentation had diminished aid effectiveness, and declared that fragmentation of Czech ODA had been substantially reduced by reduced number of priority countries.

In 2016, Czech development policy was peer-reviewed by the OECD-DAC for the second time, and this peer review made 16 recommendations, where the recommendation nr. 2.2 was formulated as follows: to continue to increase the quality and impact of its aid, the Czech Republic should focus on fewer partner countries or territories and themes (OECD, 2016, p. 16). Recommendation nr. 3.2 was focused on bilateral development cooperation as well, and called for the increase of bilateral ODA. The OECD-DAC peer review affected formulation of the next Development Cooperation Strategy that was adopted for the period of years 2018 - 2030. It introduced a renewed list of priority partner countries. For 
the period of years 2018 - 2023, Bosnia and Herzegovina, Cambodia, Ethiopia, Georgia, Moldova and Zambia were included among them (MoFA, 2017; 2021b). Thematic priorities were reformulated to reflect the 2030 Agenda for Sustainable Development, as follows: good democratic governance, sustainable management of natural resources, economic transformation and growth, agriculture and rural development, inclusive social development (MoFA, 2017).

\subsection{Dispersion of ODA}

Impact of ODA on economic growth and development is one of the commonly discussed research topics. Research studies confirmed that some preconditions for ODA effectiveness (connected with the positive impacts of ODA in recipient countries) have to be met on the side of recipient countries as well as on the side of donor countries. If the preconditions for ODA effectiveness are discussed form the perspective of recipient countries, then good governance, good policies and good overall environment are emphasized (Sachs et al., 2004; Collier and Dollar, 2002). If the preconditions for the ODA effectiveness are considered from perspective of donor countries, then attention is given particularly to ODA fragmentation and proliferation that are generally recognized as phenomena having a negative impact on aid effectiveness.

Terms fragmentation and proliferation are commonly used to show trends and main patterns of ODA flows. In general, term fragmentation is associated with ODA coming in too many small slices from too many donors (OECD, 2009), or with large numbers of donors with smaller shares on the projects' market (Knack and Rahman, 2004). Term proliferation is associated with large numbers of donors and projects (Kimura et al., 2007), or with donor countries allocating their ODA budgets among a large portfolio of recipient countries (Acharya et al., 2004). Therefore, both terms refer to dispersion of ODA across entities, which can be defined as projects, thematic sectors or countries (Hagen, 2015). In this meaning, the term dispersion is seen as the opposite to the term concentration.

Scholars connected dispersion of ODA especially with: (a) rising administrative costs (Gehring et al., 2017; OECD, 2009; Knack and Rahman, 2004); (b) administration capacities overburdening (Gehring et al., 2017), resp. overwhelming (Kimura et al., 2007); (c) existence of marginal or non-significant aid relations and duplicities (Bickenbach et al., 2017); (d) corruption (Djankov et al., 2009); (e) non or even negative impact on economic growth (Annen and Kosempel, 2009); as they can affect the outcomes of development assistance. Stronger ODA concentration and coordination of donor activities are then regarded as the means that can eliminate these negative phenomena affecting the ODA effectiveness (Bickenbach et al., 2017). 
The Paris Declaration on Aid Effectiveness launched in 2005 is a key international document focused on the improvement of aid quality. According to the Paris Declaration, donor countries would intensify effort to provide and use development assistance in ways rationalising the often-excessive fragmentation of donor activities at the country and sectoral levels by the year 2010 (OECD, 2005, p. 2.). The call for the reduction of ODA dispersion was repeated in the Accra Agenda for Action adopted in 2008. When OECD evaluated the progress in the implementation of the Paris Declaration, it found out that aid fragmentation had been worsening and the fragmentation could be an important barrier for effective development cooperation (OECD, 2012, p. 67). The issue of persisted ODA fragmentation after the adoption of Paris Declaration was addressed by some recent research studies, for instance by Gehring et al. (2017), Bickenbach et al. (2017), Hagen (2015), Nunnenkamp et al. (2013), Steinwand and Reinsberg (2020).

Level of ODA dispersion is standardly measured with the use of concentration indices, particularly Herfindahl (or Hirschman-Herfindahl) Index (HI, resp. $H H I)$ and Theil Index (TI) are the most common ones. Scholars usually apply the former one to measure ODA fragmentation (Öhler, 2017; Gehring et al., 2017; Djankov et al., 2009; Annen and Kosempel, 2009; Acharya et al., 2006; Knack and Rahman, 2004) and the latter one to measure ODA proliferation (Hagen, 2015; Nunnenkamp et al., 2013; Acharya et al., 2006). Concentration indices enable to identify an existence of one or a few large donors, or they indicate the level of ODA dispersion when no dominant donors or recipients exist (Ghering et al., 2017). $T I$ offers in its essence the possibility to be additively decomposed into two parts to analyse dispersion in more details (Acharya et al., 2006; Hagen, 2015; Bickenbach et al., 2017; Fløgstad and Hagen, 2017).

\section{Formulation of Research Problem and Methods}

Current Czech Development Cooperation Strategy introduced assessment that Czechia accepted relevantly the OECD-DAC recommendations and reduced number territorial and thematic priorities of development cooperation, which reduced dispersion of Czech ODA. The acceptation of recommendations was declared by the OECD-DAC mid-term review in June 2019 as well. Progress towards lower ODA dispersion was in both cases declared with regard to the reduced number of priority partner countries and thematic priorities. However, no research study discussing the issue of dispersion of Czech bilateral ODA has been published yet, although this issue is an actual and interesting research topic in the context of OECD-DAC peer reviews. Therefore, the aim of the research, 
which results are presented here, was to assess dispersion of Czech ODA disbursements allocated to priority partner countries with the use of bilateral development projects between years 2011 and 2019, and to show whether any progress towards lower ODA dispersion has been made since the year 2011. Research objective was framed with two research questions $(R Q)$, formulated as follows:

- RQ1: Has Czechia made a progress towards lower dispersion of ODA disbursements allocated with the use of bilateral projects since the year 2011?

- RQ2: Has Czechia contributed to the global ODA dispersion through too dispersed ODA allocations in priority partner countries?

Different data sources offer different views on Czech ODA flows. Presented research dealt with annual disbursements allocated with the use of bilateral development projects implemented, realised and monitored under the responsibility of the Czech Development Agency (CZDA) in priority partner countries, as they were under the direct control of Czechia and corresponded to its territorial and sectoral priorities. Volumes of ODA disbursements are presented in the annual reports of CZDA, but in details necessary for the analysis of ODA dispersion, data have been available since 2011. Reports assign every disbursement to a theme/sector and a recipient country, and to a contractor of a project as well. However, a title of the project, its time schedule and a form of financing are not specified. Therefore, in presented research, ODA disbursements are considered separately on annual basis. To make the results and findings more understandable, data are presented in USD, when the volumes of ODA were transferred to USD with the use of the exchange rate set by the Czech National Bank on 1 January 2021 (1 USD = 21.40 CZK).

Dispersion of ODA between priority partner countries and within these countries was assessed with the use of Theil Index. Standard TI defined by Cadot et al. (2011) for the analysis of export dispersion was updated, when the export flows were replaced with the ODA disbursements. Cadot et al. (2011) decomposed TI to between-subgroups component $\left(T I^{B}\right)$ and within-subgroups component $\left(T I^{\mathrm{W}}\right)$. When the ODA dispersion was considered, it was meaningful to recognize dispersion between recipient countries (assessed with $T I^{B}$ ) and dispersion between thematic sectors recognized within recipient countries (assessed with $T I^{W}$ ).

Theil Index was calculated in one year as follows:

$$
T I=\frac{1}{N} \sum_{n=1}^{N} \frac{x_{n}}{\bar{x}} \ln \left(\frac{x_{n}}{\bar{x}}\right)=\sum_{n=1}^{N} \frac{x_{n}}{X} \ln \left(N \frac{x_{n}}{X}\right)
$$

which can be additively decomposed to $T I^{B}$ and $T I^{W}$, it means

$$
T I^{B}+T I^{W}=T I
$$




$$
\begin{gathered}
T I^{B}=\sum_{n=1}^{N} \frac{x_{n}}{X} \ln \left(N \frac{x_{n}}{X}\right) \\
T I^{W}=\sum_{n=1}^{N} \frac{x_{n}}{X}\left[\sum_{s=1}^{S} \frac{x_{n s}}{x_{n}} \ln \left(S \frac{x_{n s}}{x_{n}}\right)\right]
\end{gathered}
$$

where

$N$ - means total number of potential recipient countries,

$X$ - the total volume of ODA allocated to $N$ potential recipient countries,

$x_{n}$ - ODA allocated to a recipient country $n$,

$\bar{x}-$ is the average ODA allocated to recipient countries, calculated as $\frac{X}{N}$,

$S$ - total number of potential sectors for ODA allocation in recipient countries,

$x_{n s}-$ ODA allocated to a sector $s$ in a recipient country $n$.

Equations (3) and (4) correspond to the $T I$ decomposition made by Fløgstad and Hagen (2017). According to Fløgstad and Hagen (2017), TI was calculated with the use of $N$ and $S$ defined as the numbers of potential recipient countries $(N)$ or thematic sectors $(S)$. This adjustment allows to solve the double-zero problem. Although shares of countries (sectors) with no recorded ODA equalled zero, they decreased the dispersion as ODA was more concentrated when it was delivered only to some potential countries (sectors). In general, values of $T I$ ranges from 0 . The value of 0 means absolute equality in ODA distribution and thus the highest dispersion, because ODA is allocated to all entities in the same proportion of total ODA flows, and this proportion equals $1 / N$, resp. $1 / S$. The maximum value of $T I$ is limited with $\ln (N)$, resp. $\ln (S)$. Maximum value of $T I$ is reached if ODA is perfectly concentrated. Here, numbers of potential priority partner countries $(N)$ and thematic priorities/sectors $(S)$ were defined according to the Czech development cooperation strategies. The numbers of priority partner countries accounted for 10 between years 2011 and 2017, and for 9 between years 2018 and 2019. Between years 2011 and 2018, ODA disbursements were classified to 13 thematic sectors. In 2019, a new classification was introduced, and number of sectors was reduced to 7 .

Dispersion of Czech ODA between bilateral projects in priority countries was assessed with the use of Herfindahl Index (HI) because no specification of the potential number of projects existed. Assessment dealt with the actual numbers of projects $(P)$.

Standard HI defined by Cadot et al. (2011) for the analysis of export dispersion was updated, when the export flows were replaced with the ODA disbursements. Herfindahl Index was calculated for ODA disbursements allocated to bilateral projects in one recipient country $n$ in one year as follows: 


$$
H I_{n}=\sum_{p=1}^{P}\left(\frac{x_{n p}}{x_{n}}\right)^{2}
$$

where

$P$ - means actual number of bilateral projects used to allocated ODA disbursements in a recipient country $n$,

$x_{n p}-$ ODA disbursements allocated to a project $p$ in a recipient country $n$.

Herfindahl Index ranges from 0 to 1, when a higher value indicated that ODA disbursements were allocated to fewer projects and thus lower ODA dispersion was measured (Gehring et al., 2017; Kannan and Rahman, 2004).

The relationship between volumes of ODA disbursements and their dispersion between projects in recipient countries, and the strength of this relationship was assessed with the use of Pearson Correlation Coefficient, calculated in the form of Pearson Product-Moment Correlation (PCC) defined for one year as follows:

$$
P C C=\frac{\sum_{i}^{I}=1\left(x_{i}-\bar{x}\right)\left(y_{i}-\bar{y}\right)}{\sqrt{\left(x_{i}-\bar{x}\right)^{2}\left(y_{i}-\bar{y}\right)^{2}}}
$$

where

I - means number of countries with non-zero volume of ODA disbursements,

$x_{i}$ - means total volume of ODA disbursed to a recipient country $i$,

$\bar{x}$ - the mean volume of ODA disbursements allocated to recipient countries $I$,

$y$ - means value of $H I$ founded for a recipient country $i$,

$\bar{y}$ - the mean value of $H I$ founded for recipient countries $I$.

Pearson Correlation Coefficient assesses the linear relationship/correlation between two sets of data, and its values ranges from -1 to 1 . Values close to 1 , resp. -1 , indicate strong relationship between $x$ and $\mathrm{y}$, either positive or negative. Here, $P C C$ assessed the relationship between volumes of ODA disbursements $(x)$ and values of $H I(y)$.

\section{Main Results and Findings}

With respect to formulated aim, assessment of ODA dispersion was divided into two parts: the first part was focused on dispersion between and within recipient countries, while the second part dealt with dispersion from the perspective of bilateral projects realized in recipient countries. 


\subsection{Dispersion of ODA between and within Priority Partner Countries}

Between years 2011 and 2019, Czechia disbursed 128572050 USD with the use of bilateral projects realized under the responsibility of CZDA in priority countries, and realized 836 disbursements related to these projects. The OECDDAC recommended Czechia in the peer review launched in 2016 to increase bilateral ODA, and bilateral projects offered the direct possibility for such increase. However, volumes of the ODA disbursements have declined since 2015, after strong increase between years 2014 and 2015 (see Figure 1). The sharp decline was identified especially between years 2017 and 2018, when bilateral ODA disbursements declined by 2.6 mil. USD or by $17.35 \%$.

Figure 1

Volumes of ODA Allocated with the Use of Bilateral Projects (in USD)

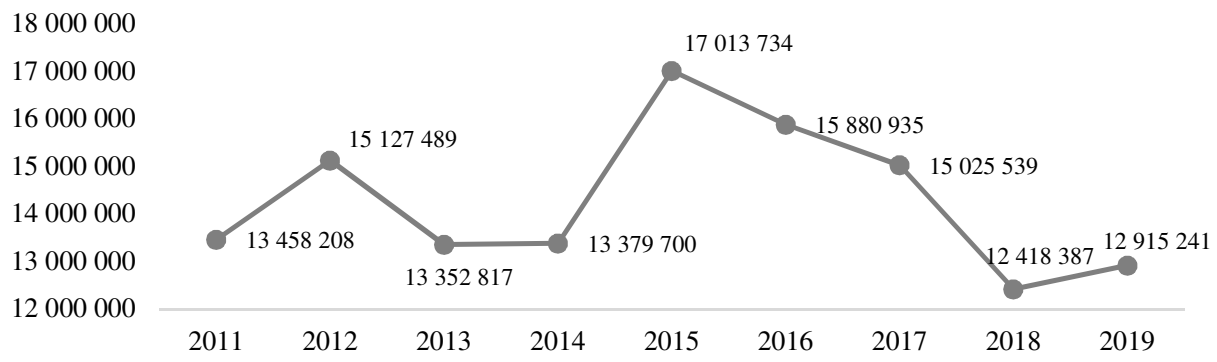

Source: CZDA (2011 - 2019), own data processing

Volumes of Czech ODA disbursements varied between priority countries and thematic priorities. Table 1 reveals that the highest volumes of ODA were allocated to Moldova, Ethiopia, Bosnia and Hercegovina. In 2018, Bosnia and Hercegovina received nearly $1 / 3$ of total volume of ODA disbursements, comparably with Ethiopia and Moldova in 2019. The highest standard deviation was identified for Mongolia, which indicated significant changes in ODA disbursements allocated there. In 2011, Mongolia accounted for 24.55\% of total volume of ODA disbursements, but its share declined year-over-year and reached only $5.24 \%$ in 2017. Since 2018, Mongolia has not been included in the list of priority partner countries (see details in Appendix 1).

Results presented in Table 2 indicated that the sector called Water supplies and sanitation received the highest volumes of Czech ODA between years 2011 and 2019. The second highest ODA was assigned to the development cooperation in Agriculture. The gaps between the mean values of shares of these two sectors and shares calculated for other sectors were very wide. The highest standard deviation was identified for the priority sector Public/state administration 
and civil society as the shares of this sector on total volumes of ODA started to increase in 2016, and reached the highest value in 2018 (15.46\%). Table 2 does not reflect thematic distribution of ODA in 2019, as a new classification was applied. See details for the year 2019 and other years in Appendix 1.

Table 1

Territorial Distribution of ODA (years 2011 - 2019)

\begin{tabular}{|c|c|c|c|c|c|c|}
\hline \multirow{2}{*}{ Country } & \multirow{2}{*}{$\begin{array}{c}\text { Volume of ODA } \\
\text { disbursements (USD) }\end{array}$} & \multirow{2}{*}{$\begin{array}{l}\text { Not included among } \\
\text { priority partner } \\
\text { countries (years) }\end{array}$} & \multicolumn{4}{|c|}{$\begin{array}{c}\text { Shares on total volumes } \\
\text { of ODA disbursements (\%) }\end{array}$} \\
\hline & & & $\begin{array}{l}\text { Mean } \\
\text { value }\end{array}$ & $\begin{array}{l}\text { Max } \\
\text { value }\end{array}$ & $\begin{array}{l}\text { Min } \\
\text { value }\end{array}$ & Deviation \\
\hline Afghanistan & 5822962 & 2018, 2019 & 5.64 & 8.97 & 1.39 & 2.27 \\
\hline Bosnia and Hercegovina & 22341716 & & 17.46 & 26.73 & 11.71 & 4.15 \\
\hline Cambodia & 6668791 & & 5.21 & 8.62 & 3.24 & 1.72 \\
\hline Ethiopia & 24876243 & & 19.60 & 27.49 & 14.89 & 4.72 \\
\hline Georgia & 12270076 & & 9.56 & 14.42 & 4.73 & 3.12 \\
\hline Kosovo & 4277891 & 2019 & 3.62 & 4.84 & 1.46 & 1.14 \\
\hline Moldova & 28297410 & & 22.02 & 27.83 & 18.67 & 3.22 \\
\hline Mongolia & 14233230 & 2019 & 12.34 & 24.55 & 0.87 & 7.60 \\
\hline Palestine & 1685269 & 2018,2019 & 1.52 & 3.96 & 0.00 & 1.71 \\
\hline Serbia & 6463241 & 2019 & 5.56 & 11.06 & 0.87 & 3.67 \\
\hline Zambia & 1635221 & $2011-2017$ & 6.49 & 8.34 & 4.64 & 2.62 \\
\hline
\end{tabular}

Source: CZDA (2011 - 2019), own data processing.

T a b l e 2

Sectoral Distribution of ODA (years 2011 - 2018)

\begin{tabular}{|l|r|r|r|r|r|}
\hline & \multicolumn{2}{|c|}{$\begin{array}{c}\text { Volume of ODA } \\
\text { disbursements } \\
\text { Sectors/Thematic priorities }\end{array}$} & \multicolumn{3}{|c|}{$\begin{array}{c}\text { Shares of total volumes of ODA } \\
\text { disbursements (\%) }\end{array}$} \\
\cline { 3 - 6 } & (USD) & $\begin{array}{c}\text { Mean } \\
\text { value }\end{array}$ & $\begin{array}{c}\text { Max } \\
\text { value }\end{array}$ & $\begin{array}{c}\text { Min } \\
\text { value }\end{array}$ & Deviation \\
\hline Agriculture, forestry, fishing & $\mathbf{2 4 9 9 8 \mathbf { 4 7 3 }}$ & $\mathbf{2 1 . 5 0}$ & $\mathbf{2 8 . 7 5}$ & 16.20 & 3.93 \\
Disaster prevention and preparedness & 870291 & 0.68 & 1.82 & 0.00 & 0.81 \\
Education & 10095267 & 8.87 & 11.22 & 5.36 & 1.82 \\
Energy, production and distribution & $\mathbf{1 3 6 2 3 ~ 3 4 7}$ & $\mathbf{1 1 . 6 6}$ & 14.98 & 8.02 & 2.89 \\
Environmental protection & 3331297 & 2.84 & 4.41 & 0.74 & 1.31 \\
Health care & 10063731 & 8.81 & 16.58 & 5.57 & 3.39 \\
Humanitarian and food aid & 93458 & 0.09 & 0.69 & 0.00 & 0.25 \\
Industry, mineral mining, construction & 342522 & 0.27 & 1.30 & 0.00 & 0.51 \\
Other social infrastructure and services & 12195187 & 10.42 & 13.50 & 7.07 & 2.66 \\
Population policies, Reproductive health care & 385894 & 0.31 & 1.45 & 0.00 & 0.59 \\
Public/State administration and civil society & 7636112 & 6.63 & $\mathbf{1 5 . 4 6}$ & 0.72 & $\mathbf{5 . 3 1}$ \\
Trade and other services & 2612500 & 2.37 & 10.11 & 0.00 & 3.51 \\
Water supplies and sanitation & $\mathbf{2 9 4 0 8 7 3 0}$ & $\mathbf{2 5 . 5 4}$ & $\mathbf{3 2 . 8 0}$ & 17.40 & 4.39 \\
\hline
\end{tabular}

Source: CZDA (2011 - 2019), own data processing.

Above presented results indicated possible dispersion of Czech ODA, but they did not show anything about the dispersion between and within countries, when they are considered simultaneously. To consider them, components of TI $\left(T I^{B}\right.$ and $\left.T I^{W}\right)$, defined by Equations (3) and (4), were used. See values of $T I$ in Figure 2 and Appendix 1. 
Low values of $T I^{B}$ indicated that ODA was more dispersed from the perspective of its distribution between recipient countries, while higher values of $T I^{W}$ indicated more concentrated ODA from the perspective of its distribution among thematic sectors recognized within these countries. Values of $T I^{B}$ declined between years 2011 and 2016 (from 0.3667 to 0.2066), which can be assessed as increasing dispersion of ODA. Relatively low values of $T I^{B}$ can be interpreted as more equal ODA distribution between recipient countries. Values of $T I^{B}$ started to increase in 2017, and indicated thus progress towards lower ODA dispersion. The maximum value of $T I^{B}$ was reached in $2019(0.5520)$. Values of $T I^{B}$ were increased especially by countries, which $x_{n}$ was higher than $\bar{x}$.

Figure 2

\section{ODA Dispersion Between and within Recipient Countries - TI Components}

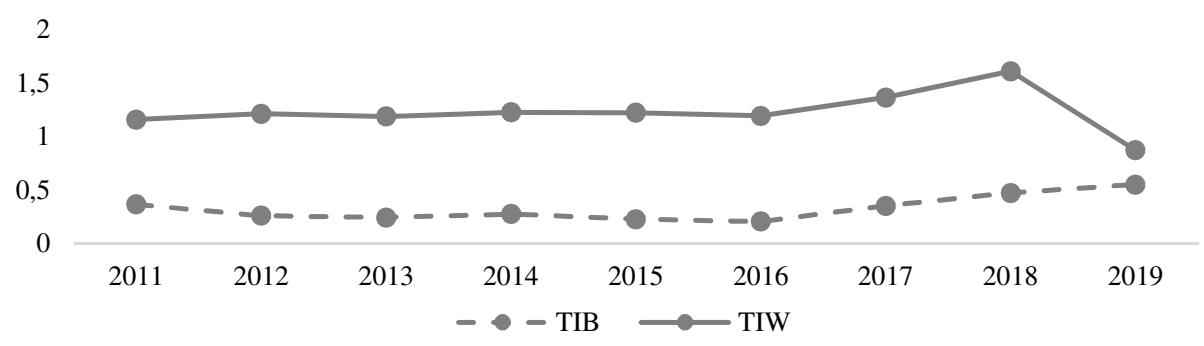

Source: CZDA (2011 - 2019), own data processing.

Figure 3

\section{Contributions of Recipient Countries to the Final $T^{W}$ Values}

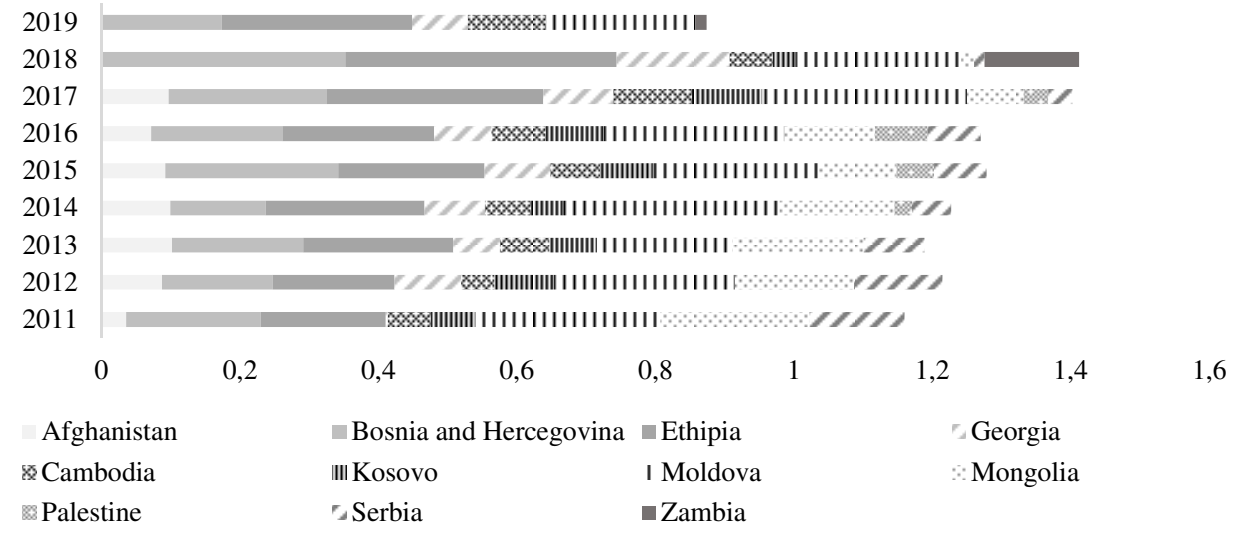

Source: CZDA (2011 - 2019), own data processing.

Values of $T I^{W}$ were quite high during the period of years $2011-2019$. They declined in 2019, when the new thematic ODA classification was applied. Results showed that ODA was more equally distributed between reduced number of 
sectors. Values of $T I^{W}$ were affected by levels of ODA dispersion between thematic sectors in recipient countries, and their shares on total volumes of ODA. Recipient countries with higher values of their $T I^{W}$ (countries with more thematically concentrated ODA) and higher shares on total volumes of ODA affected the final values of $T I^{W}$ more significantly than other countries. Contributions of Bosnia and Hercegovina, Ethiopia, Moldova and Mongolia were the most significant ones (especially in the first years of the given period). First three countries defined about $50 \%$ of the final $T T^{W}$ values between years 2011 and 2017, and in 2018 and 2019 even about $70 \%$ of $T I^{W}$ values. See values of $T I^{W}$ in Figure 3 and in Appendix 1.

\subsection{Dispersion of ODA Disbursements Allocated to Bilateral Projects}

Bilateral projects examined here were implemented under the responsibility of CZDA. They were realized by private and public contractors in relation to public proposals announced by the CZDA. Every public proposal specified eligible contractors, and territorial and sectoral targeting of the projects as well. Therefore, targeting of the projects was under the direct control of CZDA.

Results presented in Table 3 and Appendix 2 revealed that average annual volumes of ODA allocated to recipient countries varied. Moldova, Ethiopia, Bosnia and Hercegovina received the highest average volumes (see Table 3). Dispersion of ODA between projects was assessed with the use of Herfindahl Index. Its values were affected with the volumes of ODA disbursements and with their numbers (see Table 4). As dispersion was assessed on annual basis, one ODA disbursement was considered a separate project regardless the existence of multiyear projects.

Table 3

Volumes of ODA Allocated to Recipient Countries (years 2011 - 2019)

\begin{tabular}{|c|c|c|c|c|c|}
\hline \multirow[b]{2}{*}{ Country } & \multirow{2}{*}{$\begin{array}{l}\text { Not included in priority } \\
\text { partner countries (years) }\end{array}$} & \multicolumn{4}{|c|}{ Volumes of ODA disbursements (USD) } \\
\hline & & $\begin{array}{c}\text { Mean } \\
\text { volume }\end{array}$ & $\begin{array}{c}\text { Max } \\
\text { volume }\end{array}$ & $\begin{array}{c}\text { Min } \\
\text { volume }\end{array}$ & Deviation \\
\hline Afghanistan & 2018, 2019 & 831852 & 1200155 & 186916 & 318825 \\
\hline Bosnia and Hercegovina & & 2482413 & 3319658 & 1566737 & 562978 \\
\hline Cambodia & & 740977 & 1113585 & 413154 & 230354 \\
\hline Ethiopia & & 2764027 & 3550103 & 2004100 & 526755 \\
\hline Georgia & & 1363342 & 1862134 & 635948 & 435480 \\
\hline Kosovo & 2019 & 534736 & 726542 & 181215 & 198131 \\
\hline Moldova & & 3144157 & 3711163 & 2343461 & 527556 \\
\hline Mongolia & 2019 & 1779154 & 3303882 & 108031 & 1039474 \\
\hline Palestine & 2018, 2019 & 240753 & 629504 & 0 & 281020 \\
\hline Serbia & 2019 & 807905 & 1519037 & 72158 & 521588 \\
\hline Zambia & $2011-2017$ & 817611 & 1036161 & 599061 & 309076 \\
\hline
\end{tabular}

Source: CZDA (2011 - 2019), own data processing. 
Results presented in Table 4 showed that the numbers of ODA disbursements varied significantly, which indicated that ODA should have been allocated to some recipient countries with the use of too many small disbursements. In general, projects of small size are considered to have only limited impact on development in recipient countries, and small projects can contribute to global ODA dispersion. Therefore, the first results presented in Tables 3 and 4 indicated that Czechia probably contributed to the ODA dispersion recognized at the global level.

T a ble 4

Numbers of ODA Disbursements Allocated to Recipient Countries (years $2011-2019$ )

\begin{tabular}{|c|c|c|c|c|c|c|c|c|c|c|c|}
\hline Country & 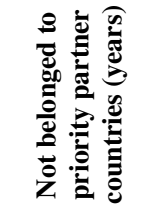 & $\overline{\bar{ন}}$ & 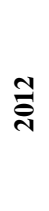 & 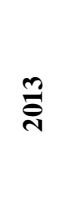 & 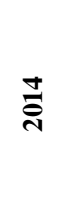 & $\stackrel{n}{\stackrel{0}{8}}$ & 룽 & $\stackrel{ }{\bar{d}}$ & $\stackrel{\infty}{\overline{\widetilde{d}}}$ & $\stackrel{\partial}{\bar{ন}}$ & 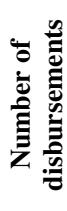 \\
\hline Afghanistan & 2018, 2019 & 1 & 5 & 5 & 8 & 3 & 3 & 3 & - & - & 28 \\
\hline Bosnia and Hercegovina & & 6 & 12 & 13 & 16 & 17 & 16 & 18 & 28 & 8 & 134 \\
\hline Cambodia & & 4 & 3 & 6 & 6 & 5 & 5 & 7 & 5 & 5 & 46 \\
\hline Ethiopia & & 12 & 12 & 15 & 14 & 17 & 15 & 16 & 16 & 13 & 130 \\
\hline Moldova & & 14 & 15 & 23 & 20 & 29 & 26 & 28 & 16 & 12 & 183 \\
\hline Mongolia & 2019 & 11 & 14 & 15 & 5 & 7 & 6 & 4 & 2 & - & 64 \\
\hline Georgia & & 7 & 14 & 12 & 15 & 24 & 20 & 19 & 20 & 8 & 139 \\
\hline Kosovo & 2019 & 4 & 6 & 8 & 5 & 5 & 5 & 5 & 2 & - & 40 \\
\hline Palestine & 2018, 2019 & 0 & 0 & 0 & 5 & 4 & 3 & 2 & - & - & 14 \\
\hline Serbia & 2019 & 7 & 7 & 5 & 9 & 12 & 5 & 1 & 1 & - & 47 \\
\hline Zambia & $2011-2017$ & - & - & - & - & - & - & - & 7 & 4 & 11 \\
\hline Number of disbursements & & 66 & 88 & 102 & 103 & 123 & 104 & 103 & 97 & 50 & 836 \\
\hline
\end{tabular}

Source: CZDA (2011 - 2019), own data processing.

Values of $H I$ presented in Figure 4 confirmed that lower ODA dispersion, or higher values of $H I$, were reached in recipient countries with lower volumes of ODA and with lower number of ODA disbursements. These findings revealed that higher volumes of ODA were associated with their higher dispersion, it means with higher numbers of disbursements. This relationship was found for Moldova, Ethiopia, Georgia, Bosnia and Hercegovina (see the values of $H I$ in Appendix 2).

The strength of the relationship between the volumes of ODA and their dispersion between individual projects (values of $H I$ ) was assessed with the use of $P C C$ defined by Equation (6). Values of PCC indicated strong, or even very strong, negative relationship between these variables (see Table 5). The highest value of $P C C$ was reached in 2019, which resulted from very high volumes of ODA allocated to Ethiopia and Moldavia (75, resp. 76 mil. USD) and higher numbers of ODA disbursements (13, resp. 12). 
Figure 4

ODA Dispersion between Projects Realized in Recipient Countries - Values of HI

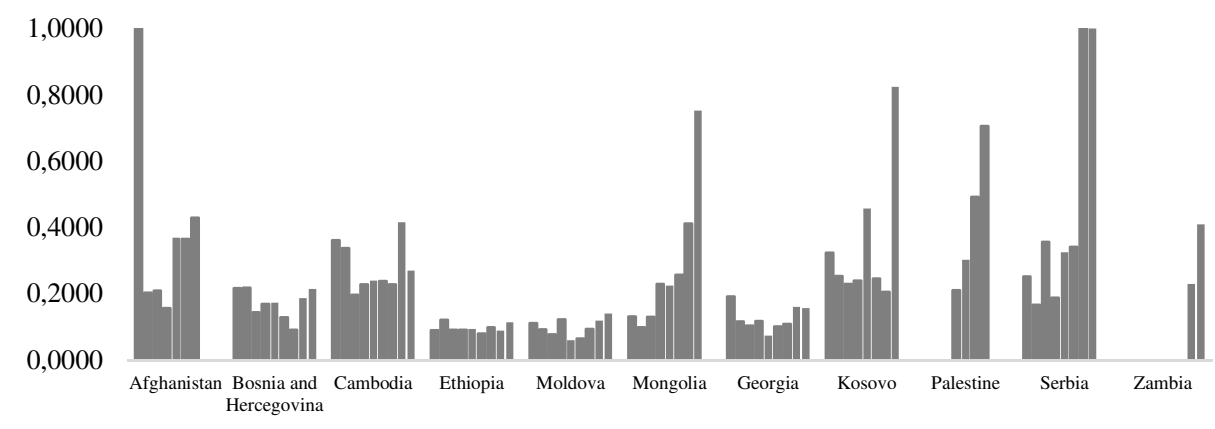

Source: CZDA (2011 - 2019), own data processing.

T a ble 5

Relationship between Volumes of ODA Disbursements and HI - Values Of PCC

\begin{tabular}{|c|c|c|c|c|c|c|c|c|}
\hline $\mathbf{2 0 1 1}$ & $\mathbf{2 0 1 2}$ & $\mathbf{2 0 1 3}$ & $\mathbf{2 0 1 4}$ & $\mathbf{2 0 1 5}$ & $\mathbf{2 0 1 6}$ & $\mathbf{2 0 1 7}$ & $\mathbf{2 0 1 8}$ & $\mathbf{2 0 1 9}$ \\
\hline-0.6426 & -0.7648 & -0.5902 & -0.6444 & -0.7750 & -0.8012 & -0.7303 & -0.8185 & $\mathbf{- 0 . 8 7 5 7}$ \\
\hline
\end{tabular}

Source: CZDA (2011 - 2019), own data processing.

Presented results corresponded to the expectations about the contribution of Czechia to the global ODA dispersion. Presented findings indicated that higher volumes of ODA disbursements were related to lower values of $H I$ and thus to more dispersed ODA. These disturbing findings opened space for the formulation of political recommendations, as well as for further research focused on the effectiveness of Czech bilateral development cooperation.

\section{Summary and Conclusions}

Dispersion of ODA is generally regarded as a factor having a negative impact on ODA effectiveness, and thus as a factor affecting the impact of ODA on development in recipient countries. Research, which results were presented above, was the first one that assessed the dispersion of Czech ODA allocated to priority partner countries with the use of bilateral development projects. Research dealt with ODA disbursements realized between years 2011 and 2019 under the responsibility of Czech Development Agency. The research wanted to answer following research questions: RQ1: Has Czechia made a progress towards lower dispersion of ODA allocated with the use of bilateral projects since the year 2011?; RQ2: Has Czechia contributed to the global ODA dispersion through too dispersed ODA allocations in priority partner countries? 
The research applied standard methods used for the assessment of ODA dispersion. Data were taken from the annual reports of the Czech Development Agency and covered the period between years 2011 and 2019. The research was divided into two parts, first was focused on $R Q 1$, and the second on $R Q 2$. In the first part, an attention was given to the dispersion of specified Czech ODA between and within recipient countries. The components of Theil Index were calculated. It was founded that values of $T I^{W}$ were higher than the values of $T I^{B}$ during the whole period. Values of $T I^{B}$ even declined between years 2011 and 2016 (from 0.3667 to 0.2066 ), which can be assessed as the increasing ODA dispersion. However, values of $T I^{B}$ started to increase in 2017, which indicated progress towards lower ODA dispersion. The maximum value of $T I^{B}$ was reached in 2019 (0.5520) because of reduced number of priority partner countries. Values of $T I^{W}$ were affected by ODA dispersion between thematic priorities in recipient countries and their shares on total ODA volumes. The highest value of $T I^{W}$ was reached in 2018 (1.6105). Higher values of $T I^{W}$ indicated that ODA was more concentrated in recipient countries with higher shares on total volumes of ODA. These findings confirmed that Czechia made progress towards lower ODA dispersion.

The second part of research wanted to show whether Czechia contributed between years 2011 and 2019 to the global ODA dispersion. To answer the $R Q 2$, dispersion of ODA disbursements allocated with the use of bilateral projects was assessed from the perspective of recipient countries with the use of Herfindahl Index. Values of $H I$ and their relationship with the volumes of ODA disbursements revealed that countries receiving higher volumes of Czech ODA received more dispersed ODA. It means that increasing ODA allocations were accompanied with their higher dispersion. The most dispersed ODA was identified for Bosnia and Hercegovina, Ethiopia, Moldova and Georgia. However, the first three countries had the most concentrated ODA within sectors (according to the values of $T I^{W}$ ). These findings were disturbing, because they indicated that the possible positive impact of Czech ODA was decreased by its higher dispersion between bilateral development projects realized within the same sector in recipient countries. These findings confirmed that Czechia probably contributed between years 2011 and 2019 to the global ODA dispersion.

Findings of the research were partly limited with the focus of the analysis that dealt only with the bilateral ODA allocated to priority partner countries. However, Czechia allocated bilateral ODA also to other ODA recipient countries and allocated ODA through the channel of multilateral institutions as well. However, bilateral ODA disbursements were chosen for the analysis as their targeting was under the direct control of the Czech Development Agency and they should have corresponded to Czech territorial and thematic priorities. Despite this fact, findings 
presented above confirmed that Czechia accepted the OECD-DAC recommendation and reduced its ODA dispersion, when ODA distributed with the use of bilateral development projects was assessed. However, ODA was allocated to recipient countries with the use of too many small disbursements, which could have negative impact on effectiveness of Czech ODA, and thus it could limit its positive impact on development in recipient countries. According to presented results, Czechia should maintain lowered number of territorial and thematic priorities. However, the Czech Development Agency should launch a new system of grants and tenders to realize fewer numbers of bilateral projects of larger size as such projects could increase the positive impact of Czech ODA in priority partner countries.

\section{References}

ACHARYA, A. - FUZZO DE LIMA, A. F. - MOORE, M. (2004): Aid Proliferation: How Responsible Are the Donors? [IDS Working Paper 214.] Brighton: Institute of Development Studies. Available at: $<$ https://opendocs.ids.ac.uk/opendocs/handle/20.500.12413/4009>.

ACHARYA, A. - FUZZO DE LIMA, A. T. - MOORE, M. (2006): Proliferation and Fragmentation: Transactions Costs and the Value of Aid. Journal of Development Studies, 42, No. 1, pp. 1 - 21. DOI: 10.1080/00220380500356225.

ANNEN, K. - KOSEMPEL, S. (2009): Foreign Aid, Donor Fragmentation, and Economic Growth. The B. E. Journal of Macroeconomics, 9, No. 1, pp. 1 - 32. DOI: 10.2202/1935-1690.1863.

BICKENBACH, F. - MBELU, A. - NUNNENKAMP, P. (2017): Is Foreign Aid Concentrated Increasingly on Needy and Deserving Recipient Countries? An Analysis of Theil Indices, 1995 - 2015. [Working Paper, No. 2078.] Kiel: Kiel Institute for the World Economy. Available at: $<$ https://ideas.repec.org/p/zbw/ifwkwp/2078.html $>$.

BICKENBACH, F. - MBELU, A. - NUNNENKAMP, P. (2019): Is Foreign Aid Concentrated Increasingly on Needy and Deserving Recipient Countries? An Analysis of Theil Indices, 1995 - 2015. World Development, 115, pp. 1 - 16. DOI: 10.1016/j.worlddev.2018.11.003.

CADOT, O. - CARRERE, C. - STRAUSS-KAHN, V. (2011): Trade Diversification: Drivers and Impacts. In: JANSEN, M., PETERS, R. and SALAZAR XIRINACHS, J. M. (eds): Trade and Employment: From Myths to Facts. Geneva: International Labour Office.

CARRCELLI, S. (2018): Bureaucracy at the Border: The Congressional Fragmentation of US Foreign Aid. [UC San Diego Electronic Theses and Dissertations.] La Jolla, CA: University of California San Diego. [Cit. 19. 11. 2021.] Available at: $<$ https://escholarship.org/uc/item/01w968qx>.

COLLIER, P. - DOLLAR, D. (2002): Aid Allocation and Poverty Reduction. European Economic Review, 46, No. 8, pp. 1475 - 1500. DOI: 10.1016/S0014-2921(01)00187-8.

CZECH DEVELOPMENT AGENCY (2011 - 2019): Výroční zprávy. [Cit. 1. 4. 2020.] Available at: <http://www.czechaid.cz/o-nas/zakladni-dokumenty/>.

CZECH DEVELOPMENT AGENCY (2021): About Us. [Cit. 22. 01. 2021.] Available at: $<$ http://www.czechaid.cz/en/about-us/ $>$.

CZECHIA (2010): Act of 21 April 2010 on Development Cooperation and Humanitarian Aid, and Amending Related Laws. [Cit. 30. 10. 2019.] Available at: $<$ https://www.mzv.cz/public/51/66/1/541617_437009_Act_on_Development_Cooperation.pdf>.

DALGAARD, C.-J. - HANSEN, H. - TRAP, F. (2004): On the Empirics of Foreign Aid and Growth. The Economic Journal, 114, No. 496, pp. F191 - F216.

DOI: $10.1111 /$ j.1468-0297.2004.00219.x. 
DJANKOV, S. - MONTALVO, J. G. - REYNAL-QUEROL, M. (2009): Aid with Multiple Personalities. Journal of Comparative Economics, 37, No. 2, pp. 217 - 229. DOI: 10.1016/j.jce.2008.09.005.

EASTERLY, W. (2007): Was Development Assistance a Mistake? The American Economic Review, 97, No. 2, pp. 328 - 332. DOI: 10.1257/aer.97.2.328.

FLØGSTAD, C. - HAGEN, R. J. (2017): Aid Dispersion: Measurement in Principle and Practice. World Development, 97, pp. 232 - 250. DOI: 10.1016/j.worlddev.2017.04.022.

GEHRING, K. - MICHAELOWA, K. - DREHER, A. - SPÖRRI, F. (2017): Aid Fragmentation and Effectiveness: What Do We Really Know? World Development, 99, pp. 320 - 334. DOI: 10.1016/j.worlddev.2017.05.019.

HAGEN, R. J. (2015): Concentration Difficulties. An Analysis of Swedish Aid Proliferation. [Rapport 2015:03 till Epertgruppen för biståndsanalys EBA.] Stockholm: Epertgruppen för biståndsanalys EBA. Available at:

$<$ https://www.oecd.org/derec/sweden/Concentration-difficulties-analysis-swedish-aidprofileration.pdf $>$.

HARMÁČEK, J. - SYROVÁTKA, M. - OPRŠAL, Z. (2017): Analýza faktorů selekce a alokace české rozvojové pomoci s využitím panelových dat a metod Probit a Tobit. Politická ekonomie, 65, No. 2, pp. 179 - 197. DOI: 10.18267/j.polek.1135; 10.18267/j.polek.1135.

HORKÝ, O. (2011): Depoliticization, Instrumentalization and Legitimacy of Czech Development Cooperation: A Case of Imposed Altruism? Éthique et économique/Ethics and Economics, 8, No. 1 , pp. $120-132$.

KILBY, CH. (2011): What Determines the Size of Aid Project? World Development, 39, No. 11, pp. 1981 - 2011. DOI: 10.1016/j.worlddev.2011.07.023.

KIMURA, H. - SAWADA, Y. - MORI, Y. (2007): Aid Proliferation and Economic Growth: A Cross-Country Analysis. [RIETI Discussion Paper Series 07-E-044.] Tokyo: The Research Institute of Economy, Trade and Industry. Available at: $<$ https://www.rieti.go.jp/jp/publications/dp/07e044.pdf $>$.

KNACK, S. - RAHMAN, A. (2004): Donors Fragmentation and Bureaucratic Quality in Aid Recipients. [World Bank Policy Research Working Paper 3186.] Washington, DC: World Bank. Available at: <https://openknowledge.worldbank.org/handle/10986/14201>.

KRYLOVÁ, P. - SYROVÁTKA, M. - OPRŠAL, Z. (2012): Assessing the Aid Effectiveness of the Czech Republic: Commitment to Development Index and Beyond. Perspectives on European Politics and Society, 13, No. 1, pp. 100 - 116. DOI: 10.1080/15705854.2011.649170.

MAJEROVÁ, I. (2013): Czech International Development Policy in the Context of EU Enlargement. Journal of Eastern Europe Research in Business \& Economics, 2013, pp. $1-10$.

MALLIK, G. (2008): Foreign Aid and Economic Growth: A Cointegration Analysis of the Six Poorest African Countries. Economic Analysis and Policy, 38, No. 2, pp. 251 - 260. DOI: 10.1016/S0313-5926(08)50020-8.

MINISTRY OF FOREIGN AFFAIRS (2001): Koncepce zahraniční rozvojové pomoc České republiky na období let 2002 až 2007. [Cit. 1. 8. 2020.] Available at: $<$ https://www.mzv.cz/public/7/36/4a/18290_14945_zrp_cz.pdf>. [Accessed 28 June, 2020.]

MINISTRY OF FOREIGN AFFAIRS (2010): Development Cooperation Strategy of the Czech Republic 2010 - 2017. [Cit. 1. 8. 2020.] Available at: <http://www.czechaid.cz/wp-content/ uploads/2016/09/Development_Cooperation_Strategy_2010_2017.pdf $>$.

MINISTRY OF FOREIGN AFFAIRS (2017): Development Cooperation Strategy of the Czech Republic 2018 - 2030. [Cit. 1. 8. 2020.] Available at: $<$ https://www.mzv.cz/file/2710363/CZ_Development_Cooperation_Strategy_2018_2030.pdf>. MINISTRY OF FOREIGN AFFAIRS (2021a): Prioritní země 2010 - 2017. [Cit. 1. 8. 2020.] Available at:

$<$ https://www.mzv.cz/jnp/cz/zahranicni_vztahy/rozvojova_spoluprace/dvoustranna_zrs_cr/prio ritni_zeme_2010_2017/index.html>. 
MINISTRY OF FOREIGN AFFAIRS (2021b): Prioritní země 2018 - 2023. [Cit. 1. 8. 2020.] Available at: $<$ https://www.mzv.cz/jnp/cz/zahranicni_vztahy/rozvojova_spoluprace/dvoustranna_zrs_cr/prio ritni_zeme_2018_2023/index.html>.

NUNNENKAMP, P. - ÖHLER, H. - THIELE, R. (2013): Donor Coordination and Specialization: Did the Paris Declaration Make a Difference? Review of World Economics, 149, pp. 537 - 563. DOI: 10.1007/s10290-013-0157-2.

OECD (2005): Paris Declaration on Aid Effectiveness. Paris: OECD Publishing. DOI: $10.1787 / 9789264098084$-en.

OECD (2007): DAC Special Review of the Czech Republic. [Cit. 1. 8. 2020.] Paris: OECD. Available at: $<$ https://www.oecd.org/dac/peer-reviews/specialreviewoftheczechrepublicsdevelopmentcooperation2007.htm>.

OECD (2008): Accra Agenda for Action. Paris: OECD Publishing. DOI: 10.1787/9789264098107-en.

OECD (2009): Development Cooperation Report. Paris: OECD Journal on Development, 10/1. Available at: $<$ https://www.oecd-ilibrary.org/development/oecd-journal-on-development_1996580x>.

OECD (2012): Aid Effectiveness 2011: Progress in Implementing the Paris Declaration, Better Aid. Paris: OECD Publishing. DOI: 10.1787/9789264125780-en.

OECD (2016): OECD Development Co-operation Peer Reviews: Czech Republic 2016. Paris: OECD Publishing. DOI: 10.1787/9789264264939-en.

OECD (2019): OECD-DAC Czech Republic Mid-term Review. Paris: OECD. [Cit. 1. 12. 2020.] Available at: $<$ http://www.oecd.org/dac/peer-reviews/DAC-mid-term-Czech-Republic-2019.pdf > .

OECD (2021): Net ODA (indicator). [Online.] Paris: OECD. [Cit. 10. 6. 2021.] DOI: $10.1787 / 33346549$-en.

ÖHLER, H. (2017): A Micro-level Analysis of the Effects of Aid Fragmentation and Aid Alignment. [Discussion Paper, No. 7/2017.] Bonn: Deutsches Institut für Entwicklungspolitik (DIE). Available at: $<$ https://www.die-gdi.de/uploads/media/DP_7.2017.pdf $>$.

SACHS, J. D. (2005): The Development Challenge. Foreign Affairs, 84, No. 2, pp. 78 - 90. DOI: $10.2307 / 20034277$.

SACHS, J. D. (2012): From MDGs to SDGs. The Lancet, 379, No. 9832, pp. 2206 - 2211. DOI: 10.1016/S0140-6736(12)60685-0.

SACHS, J. D. et al. (2004): Ending Africa's Poverty Trap. Brookings Papers on Economic Activity, 1, pp. 117 - 240. Available at: $<$ https://www.brookings.edu/wp-content/uploads/2004/01/2004a_bpea_sachs.pdf $>$.

STEINWAND, M. C. - REINBERG, B. (2020): Multilateral Aid to the Rescue? Sectoral Fragmentation of Bilateral Development Aid and the Role of the World Bank. Available at: $<$ https://ssrn.com/abstract=3575822>.

SYROVÁTKA, M. - KRYLOVÁ, P. (2012): Aid Dimension of the Commitment to Development Index: Case Study of the Czech Republic. International Journal of Sustainable Economy, 4, No. 4, pp. 323 - 339. DOI: 10.1504/IJSE.2012.049611. 


\section{A p pendix 1}

\section{Shares of Recipient Countries on Total ODA Volumes}

\begin{tabular}{|l|r|r|r|r|r|r|r|r|r|r|}
\hline Country & $\mathbf{2 0 1 1}$ & $\mathbf{2 0 1 2}$ & $\mathbf{2 0 1 3}$ & $\mathbf{2 0 1 4}$ & $\mathbf{2 0 1 5}$ & $\mathbf{2 0 1 6}$ & $\mathbf{2 0 1 7}$ & $\mathbf{2 0 1 8}$ & $\mathbf{2 0 1 9}$ & $\begin{array}{c}\text { ODA volume } \\
\text { USD }\end{array}$ \\
\hline Afghanistan & 1.39 & 5.56 & 6.65 & 8.97 & 6.03 & 5.88 & 4.97 & - & - & 5822962 \\
Bosnia and Hercegovina & 17.35 & 13.79 & 17.01 & 11.71 & 19.27 & 16.33 & 17.92 & 26.73 & 17.01 & 22341716 \\
Cambodia & 3.87 & 3.24 & 5.95 & 5.66 & 4.67 & 5.07 & 6.52 & 3.33 & 8.62 & 6668791 \\
Ethiopia & 14.89 & 14.92 & 17.94 & 18.86 & 16.57 & 17.20 & 21.95 & 26.55 & 27.49 & 24876243 \\
Georgia & 4.73 & 7.58 & 7.39 & 7.29 & 10.64 & 9.79 & 10.99 & 13.26 & 14.42 & 12270076 \\
Kosovo & 3.50 & 4.51 & 3.98 & 2.42 & 3.99 & 4.31 & 4.84 & 1.46 & - & 4277891 \\
Moldova & 18.67 & 21.04 & 19.24 & 25.35 & 21.16 & 21.36 & 24.70 & 18.87 & 27.83 & 28297410 \\
Mongolia & 24.55 & 19.31 & 15.58 & 13.33 & 8.95 & 10.86 & 5.24 & 0.87 & - & 14233230 \\
Palestine & 0.00 & 0.00 & 0.00 & 1.52 & 3.67 & 3.96 & 1.52 & 0.00 & - & 1685269 \\
Serbia & 11.06 & 10.04 & 6.25 & 4.89 & 5.05 & 5.24 & 1.35 & 0.58 & - & 6463241 \\
Zambia & - & - & - & - & - & - & - & 8.34 & 4.64 & 1635221 \\
\hline
\end{tabular}

Source: CZDA (2011 - 2019), own data processing.

Shares of Thematic Sectors on Total ODA Volumes

\begin{tabular}{|c|c|c|c|c|c|c|c|c|c|}
\hline Thematic priority & 2011 & 2012 & 2013 & 2014 & 2015 & 2016 & 2017 & 2018 & $\begin{array}{l}\text { ODA volume } \\
\text { USD }\end{array}$ \\
\hline Agriculture, forestry, fishing & 18.14 & 16.20 & 18.87 & 21.74 & 24.49 & 21.76 & 28.75 & 22.02 & 24998473 \\
\hline Disaster prevention & & & & & & & & & \\
\hline and preparedness & 0.00 & 1.24 & 0.00 & 0.00 & 1.82 & 1.74 & 0.64 & 0.00 & 870291 \\
\hline Education & 10.15 & 9.51 & 11.22 & 8.96 & 5.36 & 7.35 & 8.67 & 9.76 & 10095267 \\
\hline Energy, production & 1453 & 1443 & 1225 & 8.02 & 14.98 & 1164 & 8.09 & 937 & 13623347 \\
\hline Environmental protection & 3.95 & 2.86 & 1.46 & 4.08 & 2.21 & 4.41 & 3.05 & 0.74 & 3331297 \\
\hline Health care & 7.21 & 5.57 & 9.03 & 16.58 & 9.14 & 6.96 & 6.99 & 8.98 & 10063731 \\
\hline Humanitarian and food aid & 0.69 & 0.00 & 0.00 & 0.00 & 0.00 & 0.00 & 0.00 & 0.00 & 93458 \\
\hline $\begin{array}{l}\text { Industry, mineral mining, } \\
\text { construction }\end{array}$ & 0.00 & 0.00 & 0.00 & 0.86 & 1.30 & 0.04 & 0.00 & 0.00 & 342522 \\
\hline $\begin{array}{l}\text { Other social infrastructure } \\
\text { and services }\end{array}$ & 7.07 & 9.06 & 13.43 & 8.01 & 11.54 & 12.71 & 13.50 & 8.04 & 12195187 \\
\hline $\begin{array}{l}\text { Population policies, } \\
\text { reproductive health }\end{array}$ & 0.00 & 0.00 & 0.00 & 1.05 & 1.45 & 0.00 & 0.00 & 0.00 & 385894 \\
\hline $\begin{array}{l}\text { Public administration } \\
\text { and civil society }\end{array}$ & 0.72 & 4.28 & 3.03 & 2.80 & 4.51 & 9.38 & 12.90 & 15.46 & 7636112 \\
\hline Trade and other services & 10.11 & 4.06 & 3.12 & 1.66 & 0.00 & 0.00 & 0.00 & 0.00 & 2612500 \\
\hline Water supplies and sanitation & 27.43 & 32.80 & 27.59 & 26.26 & 23.20 & 24.02 & 17.40 & 25.62 & 29408730 \\
\hline Thematic priority & 2019 & & & & & & & & \\
\hline Agriculture, forestry & 22.40 & & & & & & & & \\
\hline Education & 9.02 & & & & & & & & \\
\hline Energy & 10.34 & & & & & & & & \\
\hline Health & 34.96 & & & & & & & & \\
\hline Social sphere & 10.87 & & & & & & & & \\
\hline State administration & & & & & & & & & \\
\hline and civil society & 12.41 & & & & & & & & \\
\hline
\end{tabular}

Source: CZDA (2011 - 2019), own data processing.

\section{Values of TI Components}

\begin{tabular}{|l|c|c|c|c|c|c|c|c|c|}
\hline Year & $\mathbf{2 0 1 1}$ & $\mathbf{2 0 1 2}$ & $\mathbf{2 0 1 3}$ & $\mathbf{2 0 1 4}$ & $\mathbf{2 0 1 5}$ & $\mathbf{2 0 1 6}$ & $\mathbf{2 0 1 7}$ & $\mathbf{2 0 1 8}$ & $\mathbf{2 0 1 9}$ \\
\hline $\mathrm{TI}^{\mathrm{B}}$ & 0.3667 & 0.2620 & 0.2439 & 0.2779 & 0.2282 & 0.2066 & 0.3522 & 0.4737 & 0.5520 \\
$\mathrm{TI}^{\mathrm{W}}$ & 1.1599 & 1.2146 & 1.1886 & 1.2269 & 1.2239 & 1.1941 & 1.3664 & 1.6106 & 0.8739 \\
\hline
\end{tabular}

Source: Annual reports of CZDA (2011 - 2019), own data processing. 
Values $\mathbf{T I}^{\mathrm{W}}$ for Recipient Countries

\begin{tabular}{|l|c|c|c|c|c|c|c|c|l|}
\hline Country & $\mathbf{2 0 1 1}$ & $\mathbf{2 0 1 2}$ & $\mathbf{2 0 1 3}$ & $\mathbf{2 0 1 4}$ & $\mathbf{2 0 1 5}$ & $\mathbf{2 0 1 6}$ & $\mathbf{2 0 1 7}$ & $\mathbf{2 0 1 8}$ & $\mathbf{2 0 1 9}$ \\
\hline Afghanistan & 0.0356 & 0.0873 & 0.1018 & 0.0991 & 0.0919 & 0.0713 & 0.0967 & 0 & 0 \\
Bosnia and Hercegovina & 0.1941 & 0.16 & 0.1892 & 0.1379 & 0.2498 & 0.1895 & 0.2286 & 0.3519 & 0.1732 \\
Cambodia & 0.0618 & 0.0478 & 0.0713 & 0.0669 & 0.0717 & 0.078 & 0.1139 & 0.0624 & 0.1129 \\
Ethiopia & 0.1808 & 0.1759 & 0.2166 & 0.2295 & 0.2113 & 0.2196 & 0.3128 & 0.392 & 0.2749 \\
Georgia & 0.0029 & 0.0962 & 0.0677 & 0.0869 & 0.0951 & 0.083 & 0.1009 & 0.1629 & 0.0809 \\
Kosovo & 0.0637 & 0.0864 & 0.0686 & 0.0458 & 0.0765 & 0.0829 & 0.1018 & 0.0328 & 0 \\
Moldova & 0.2683 & 0.2611 & 0.1951 & 0.3129 & 0.2386 & 0.2623 & 0.2953 & 0.2394 & 0.2156 \\
Mongolia & 0.2155 & 0.1719 & 0.1907 & 0.1665 & 0.1135 & 0.1305 & 0.0817 & 0.0187 & 0 \\
Palestine & 0 & 0 & 0 & 0.0249 & 0.0543 & 0.0756 & 0.0359 & 0 & 0 \\
Serbia & 0.1372 & 0.128 & 0.0876 & 0.0566 & 0.0753 & 0.0769 & 0.0347 & 0.0149 & 0 \\
Zambia & 0 & 0 & 0 & 0 & 0 & 0 & 0 & 0.1366 & 0.0164 \\
\hline
\end{tabular}

Source: CZDA (2011 - 2019), own data processing.

\section{A p pendix 2}

Volumes of ODA Allocated to Recipient Countries (in USD)

\begin{tabular}{|c|c|c|c|c|c|c|c|c|c|}
\hline Country & 2011 & 2012 & 2013 & 2014 & 2015 & 2016 & 2017 & 2018 & 2019 \\
\hline Afghanistan & 186916 & 841121 & 887850 & 1200155 & 1025591 & 933923 & 747406 & - & - \\
\hline Bosnia and & & & & & & & & & \\
\hline Hercegovina & 2335017 & 2086260 & 2271743 & 1566737 & 3278883 & 2594123 & 2693010 & 3319658 & 2196284 \\
\hline Cambodia & 520928 & 490654 & 794393 & 757464 & 793925 & 804696 & 979991 & 413154 & 1113585 \\
\hline Ethiopia & 2004100 & 2257716 & 2395201 & 2523302 & 2818413 & 2731628 & 3298133 & 3297645 & 3550103 \\
\hline Georgia & 635948 & 1146729 & 986647 & 975522 & 1811065 & 1554054 & 1651074 & 1646903 & 1862134 \\
\hline Kosovo & 470447 & 681752 & 531941 & 323915 & 678386 & 683693 & 726542 & 181215 & \\
\hline Moldova & $\begin{array}{lll}2 & 512 & 189\end{array}$ & $\begin{array}{llll}3 & 183 & 115\end{array}$ & 2569714 & 3391805 & 3600259 & $\begin{array}{llll}3 & 391630\end{array}$ & 3711163 & 2343461 & 3594073 \\
\hline Mongolia & $\begin{array}{llll}3 & 303 & 882\end{array}$ & $\begin{array}{llll}2 & 921 & 103\end{array}$ & 2080567 & 1783113 & 1523562 & 1725258 & 787712 & 108031 & - \\
\hline Palestine & & & & 203543 & 624506 & 629504 & 227716 & - & - \\
\hline Serbia & 1488782 & 1519037 & 834760 & 654142 & 859144 & 832426 & 202791 & 72158 & - \\
\hline Zambia & - & - & - & - & - & - & - & 1036161 & 599061 \\
\hline
\end{tabular}

Source: CZDA (2011 - 2019), own data processing.

\section{Values of HI}

\begin{tabular}{|l|c|c|c|c|c|c|c|c|c|}
\hline Country & $\mathbf{2 0 1 1}$ & $\mathbf{2 0 1 2}$ & $\mathbf{2 0 1 3}$ & $\mathbf{2 0 1 4}$ & $\mathbf{2 0 1 5}$ & $\mathbf{2 0 1 6}$ & $\mathbf{2 0 1 7}$ & $\mathbf{2 0 1 8}$ & $\mathbf{2 0 1 9}$ \\
\hline Afghanistan & 1.0000 & 0.2037 & 0.2094 & 0.1566 & 0.3691 & 0.3650 & 0.4296 & - & - \\
Bosnia and Hercegovina & 0.2175 & 0.2187 & 0.1442 & 0.1690 & 0.1728 & 0.1291 & 0.0910 & 0.1866 & 0.2149 \\
Cambodia & 0.3618 & 0.3379 & 0.1972 & 0.2288 & 0.2389 & 0.2388 & 0.2282 & 0.4149 & 0.2699 \\
Ethiopia & 0.0900 & 0.1211 & 0.0915 & 0.0913 & 0.0935 & 0.0794 & 0.0994 & 0.0894 & 0.1140 \\
Moldova & 0.1114 & 0.0931 & 0.0775 & 0.1224 & 0.0602 & 0.0645 & 0.0935 & 0.1183 & 0.1404 \\
Mongolia & 0.1309 & 0.0994 & 0.1302 & 0.2294 & 0.2247 & 0.2575 & 0.4112 & 0.7521 & - \\
Georgia & 0.1922 & 0.1168 & 0.1042 & 0.1180 & 0.0740 & 0.1008 & 0.1084 & 0.1598 & 0.1571 \\
Kosovo & 0.3242 & 0.2534 & 0.2300 & 0.2394 & 0.4573 & 0.2453 & 0.2055 & 0.8241 & - \\
Palestine & 0.0000 & 0.0000 & 0.0000 & 0.2109 & 0.3023 & 0.4915 & 0.7059 & - & - \\
Serbia & 0.2522 & 0.1670 & 0.3564 & 0.1876 & 0.3256 & 0.3417 & 1.0000 & 1.0000 & - \\
Zambia & - & - & - & - & - & - & - & 0.2299 & 0.4085 \\
\hline
\end{tabular}

Source: CZDA (2011 - 2019), own data processing. 